\title{
ATTACHMENT OR ALOOFNESS AT UNIVERSITY LEVEL: ANALYZING G- LOCALIZATION OF SPACE SCIENCE EDUCATION IN THE CURRICULUM AT PRIMARY AND SECONDARY LEVEL IN PAKISTAN
}

\author{
Munir Moosa Sadruddin ${ }^{*}$
}

\begin{abstract}
This research is conducted to identify the inclusion of the concepts of space science in the textbooks, and to unveil its contribution in thrusting interest of youth towards this opportunistic field in Pakistan. The methodology is based on Quantitative Research Paradigm. Quantitative content analysis is carried out, which is triangulated with a brief survey. Two textbooks (Social Studies and Science Grade IX) are selected, whereas survey is taken from 2400 secondary level students, selected through convenience sampling. Findings notified inclusion of concepts as spineless and theoretical in the textbooks at primary level and also lack practical component. Furthermore, books at secondary level have limited content addressing in-depth concepts. Through quantitative survey it is revealed that besides conventional fields, students preferred opting for emerging fields (chi-square $=523.47$ ), yet majority did not show their interest towards space science. They also highlighted that the concepts are either not learnt or have no idea about its inclusion (chi-square $=60.73$ ). Researcher suggests improving the overall content of science and social studies books and introducing space science education as a subject. Furthermore, HEC should provide academic perks for adopting profession in emerging fields. Awareness sessions and counseling of students in this regard would be highly favorable.
\end{abstract}

Keywords: curriculum, content analysis, space science, space science education

\section{Introduction}

Globalization has brought challenges and opportunities to the field of education, which are ever escalating. The socioeconomic development of any country is based on emerging fields (Rontos \& Vavouras, 2013). Many trends are setting up new paths to meet the needs of societies. These needs are particularly met through the evolution of innovative fields.

There has been a global shift to espouse new professions to compete in the global era; however, there has also been a global chase for credentials. Majority of the youth still prefer opting for same occupational niches without exploring other career possibilities. This culture of following trend is widespread particularly in the Asian countries, keeping in view the fact that occupations, which are well- established, give more opportunities to individuals; however, as the transitions are taking place, emerging fields

\footnotetext{
* Munir Moosa Sadruddin, Ph.D. Assistant Professor, Department of Education, Sindh Madressatul Islam University, Karachi
} 
offer more scope (though gradual); but this concept cannot be justified unless discovered by youth.

In this globally competent world, challenges and opportunities are ever rising. Due to rapid advancement, youth are puzzled to find proper direction. Their first preference is always towards those magnetizing fields, which are leveraging, lucrative as well as stable. It is a hard nut to crack influencing youth to support emerging fields unless explored at large.

The role of educational institutions is to prepare global minded individuals, who can later serve country with full zest and zeal. It is also the responsibility of academic institutions to explore the hidden talent of students as well as to polish it. Further, their duty is to provide counseling and guidance to students for motivating and inspiring them to make new career choices. Education Institutions are facing challenges to direct students embarking upon those fields, which can help those gaining better employment opportunities (Arulmani et al., 2014) due to various factors.

Unfortunately, due to lack of proper counseling and guidance, traditional fields are still attracting students. Not only developed countries, but also developing countries are facing an acute need of scholars in emerging fields. There are many gaps, which are yet to be filled. Many variables contribute in shaping interest of youth towards budding fields. Role of teachers have significant impact on student's decision in choosing career in emerging fields (Kaya \& Boyuk, 2011; Stefan \& Ciomos, 2010); but teachers' knowledge and counseling skills in this regard is of great importance. Few of the research studies also highlighted the role of parents in motivating youth towards new fields (Clutter, 2010; Foskett \& Hemsley-Brown, 2002); however in majority of the cases, the choice is made by youth themselves.

Advancement in science and technology is the key feature of modern societies. Today, many emerging fields are being offered by science and technology, which has open up possibilities to bring revolutionary changes in the world. All the nations across the globe endorse its significance. It has turned ideas into design. From well-being of individuals to sustainable development, science has brought all the possible solutions to forefront. One of such promising fields, which are least noticed in Pakistan, include space science.

Space science is a mounting field in this technology driven world. It is revolutionizing life and contributing to quench the thirst of knowledge about space, environment, etc.

This field has many career possibilities and global opportunities. Global society including China, Japan, India, UK and USA acknowledge its significance, and also initiated space science education programs at the grass root level. Modeling and simulation activities are also included to develop interest of children towards space education. Their main motive is to prepare competent individuals for meeting future needs.

Science and Social Studies are considered as the most influential and profoundly important subjects to promote space science education in those countries, where it is not taught as a separate subject. In Pakistan, space science education is not taught at school 
and college level as a subject; however, few concepts are accommodated in the curriculum of science and social studies/Pakistan studies; but its nature is yet to explore. Although several workshops and conferences are taking place each year, yet the missing gaps- subject of space science education does not exist, which is a great disparity. At higher education level in Pakistan, educational institutions like SUPARCO, University of Karachi, Institute of Space Sciences, Institute of Space Technology, University of Punjab, etc offer courses in space science up to doctoral level; however, lack of exploration of this field at grass root level through the mediation of textbooks and counseling could be the reason for declining interest of youth to grip this promising field.

Importance of space science education in Pakistan is highlighted by few newspapers (The Express Tribune, 2014; Dawn Newspaper, 2011). No research study particularly focuses on the notion of space science education across the globe. A research study was conducted to find the attitude of youth towards fields of science. It was found that academic achievement in the subject of science significantly contributes in developing interest to pursue career in science (Russell, 2012); however, other research studies revealed that students lack interest in subjects like physics due to its complex nature (Mohan, 2013; Redish, 1994). The researcher predicts that youth feel hesitant to enter those fields, which lack human resources and employment prospects, because unless future possibilities are explored, youth cannot actively participate and show interest to enter new careers.

Inclusion of contemporary issues, explorative fields and global studies at primary and secondary level in Pakistan can intact students to adopt global subjects at university level and global career in the professional life. Potential subjects like science and social studies are the hub for developing interest of youth towards emerging fields in Pakistan; however no researches have so far been conducted to understand whether content of books include concepts related to space science or not? If yes, what is the nature of the content? What is the attitude of youth towards space science? Whether youth learn the concepts of space science through the textbooks or not? Whether it motivates students towards space science or not?

Keeping in mind the importance of budding curiosity in the field of space science, this pioneer research study is conducted to investigate concepts of space science in textbook at primary and secondary level in Karachi, Pakistan. This research would provide a baseline to other researchers, interested to explore other domains of space science education in Pakistan.

\section{Research Questions}

In the light of the research objectives, following research questions are designed for the present study:

1. Which field do students prefer to embark upon in future?

2. Are concepts of universe, space and planets are portrayed in the curriculum of primary and secondary level? 
3. What is the nature of the concepts in textbook?

4. Do students learn about the concepts of space science in textbooks?

\section{Research Methodology}

Quantitative Research Paradigm is used for the current study. Quantitative content analysis is carried out to identify opportunities and missing gaps, which is triangulated with a survey. The population consists of all the text books of Social Studies and Science of Sindh Text Book Boards (Grade 1-10 standards). Sample consists of all the Social Studies and Science text books, published by Sindh Text Book Boards from grade 1-10. Through purposive sampling, one book from each stratified group is selected to find inclusion of topics related to space science. For this particular research, content analyses of two secondary class books of grade 9 (Pakistan Studies and General Science) are conducted. Researcher also reviewed primary and middle level textbooks for grounding research. The research is supplemented with random survey from 2400 male and female secondary students, selected through convenience sampling from the secondary schools, working in Karachi (both public and private schools). The results of survey are analyzed using statistical test (chi-square). For ethical consideration, name of the participants and institutions are kept anonymous.

\section{Content Analysis}

Table 1. Showing the Hierarchy of Stratification

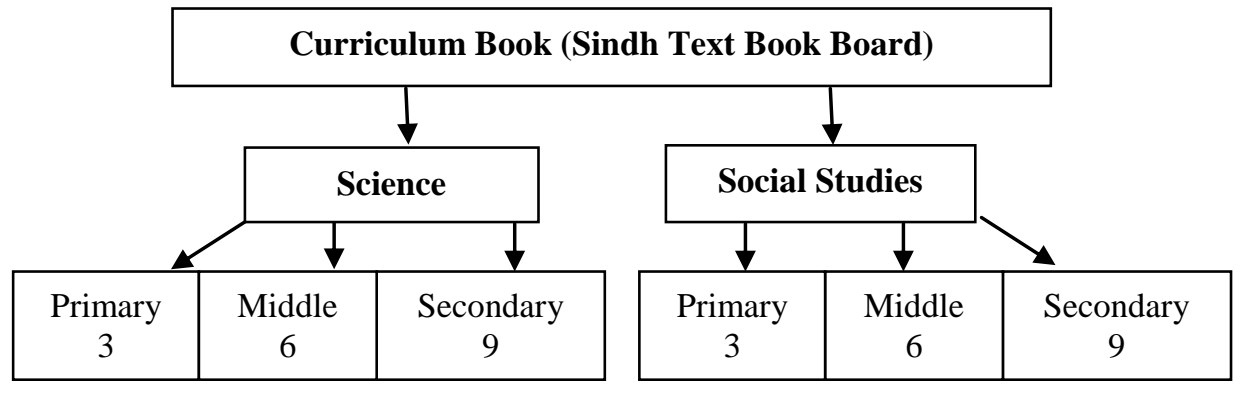

Note: Books of Science and Social/Pakistan Studies, published by Sindh Text Book Board are selected. Although there is no inclusion of analysis from primary and middle level; however, the researcher gauged it in order to give strong support to the latter concepts. 
Table 2. Showing the Concept of Universe, Space and Planet in Grade 9 Pakistan Studies

\begin{tabular}{|c|c|c|}
\hline Chapter Name & $\begin{array}{l}\text { Concept of Universe, Space \& } \\
\text { Planet }\end{array}$ & Nature \\
\hline Ideological Basis of Pakistan & - & - \\
\hline Making of Pakistan & - & - \\
\hline $\begin{array}{l}\text { Constitutional Development in } \\
\text { Islamic Republic of Pakistan }\end{array}$ & - & - \\
\hline Land and Climate of Pakistan & $\begin{array}{l}\text { Pollution, Planet Survival, } \\
\text { Features } \\
\text { of Planet and Earth Boundaries, } \\
\text { Mountains, Climate, Plateaus, } \\
\text { Plains, } \\
\text { Deserts }\end{array}$ & Theoretical \\
\hline Resources of Pakistan & $\begin{array}{l}\text { Forest, Natural Resources, } \\
\text { Agricultural } \\
\text { Resources }\end{array}$ & Theoretical \\
\hline $\begin{array}{lll}\text { Industrial } & \text { Development } \\
\text { Pakistan } & & \\
\end{array}$ & - & - \\
\hline The Population of Pakistan & - & - \\
\hline Culture of Pakistan & - & - \\
\hline Education in Pakistan & - & - \\
\hline Pakistan- A Welfare State & - & - \\
\hline
\end{tabular}

Note: Only two chapters, i.e., Land and Climate of Pakistan and Resources of Pakistan cover few concepts related to space science education; but the concepts and ideas are theoretical in nature without inclusion of any activity.

Table 3. Showing the Concept of Universe Space and Planet in Grade 9 General Sciences

\begin{tabular}{|c|c|c|}
\hline Chapter Name & $\begin{array}{l}\text { Concept of Universe, Space and } \\
\text { Planet }\end{array}$ & Nature \\
\hline $\begin{array}{l}\text { Introduction and Role of } \\
\text { Science }\end{array}$ & $\begin{array}{l}\text { Definition of Geology, Astronomy, } \\
\text { Metrology }\end{array}$ & Theoretical \\
\hline Our Life and Chemistry & - & - \\
\hline $\begin{array}{l}\text { Bio Chemistry and Bio } \\
\text { Technology }\end{array}$ & - & - \\
\hline Man and Health & - & - \\
\hline $\begin{array}{lll}\begin{array}{l}\text { Disease, } \\
\text { Prevention }\end{array} & \text { Causes } & \text { and } \\
\end{array}$ & - & - \\
\hline $\begin{array}{l}\text { Environment and Natural } \\
\text { Resource }\end{array}$ & $\begin{array}{l}\text { Physical Features like Climate, } \\
\text { Pollution, } \\
\text { Environment }\end{array}$ & Theoretical \\
\hline Energy & - & - \\
\hline
\end{tabular}




\begin{tabular}{ll|l}
\hline Current Electricity & - & - \\
\hline Basic Electronics & - & - \\
\hline Science and Technology & Satellite, Radar & Theoretical \\
\hline The Space and Nuclear & History of Space Exploration, Pakistan & Theoretical \\
Programme of Pakistan & Space & \\
& Program, Role of Suparco & \\
\hline
\end{tabular}

Note: Four chapters, i.e., Introduction and Role of Science; Environment and Natural Resource, Science and Technology and The Space and Nuclear Programme of Pakistan cover few concepts related to space science education; but the concepts and ideas are theoretical in nature without inclusion of any simulation activity.

Table 4a. Showing the Responses of Respondents towards the Field of Interest

\begin{tabular}{llllllll}
\hline S.No & Gender & Medical & Commerce & Engineering & $\begin{array}{l}\text { Space } \\
\text { Science }\end{array}$ & $\begin{array}{l}\text { Liberal } \\
\text { Arts }\end{array}$ & Total \\
\hline 1. & Male & 183 & 376 & 509 & 3 & 129 & 1200 \\
\hline 2. & Female & 521 & 249 & 110 & 7 & 313 & 1200 \\
\hline & & 704 & 625 & 619 & 10 & 442 & 2400 \\
\hline
\end{tabular}

$*$ Mean $=480$, S.D $=279.67$

Note: From the above table, it is concluded that majority of the males are interested towards Engineering $(n=509)$, followed by Commerce $(n=376)$, Medical $(n=183)$ and Liberal Arts $(n=129)$, but only three male respondents showed their interest towards space science; whereas, majority of the female respondents $(n=521)$ are interested in medical, followed by Liberal Arts $(n=313)$, Commerce $(n=249)$ and Engineering $(n=110)$, but only seven female respondents showed their interest towards space science.

Table 4b. Showing the Application of Statistical Test (Chi-Square)

\begin{tabular}{lllllll}
\hline \multicolumn{1}{l}{ Results } & \multicolumn{1}{l}{ Medical } & Commerce & Engineering & $\begin{array}{l}\text { Space } \\
\text { Science }\end{array}$ & Liberal Arts & Totals \\
\hline \multirow{2}{*}{ Male } & $183(352.00)$ & $376(312.50)$ & $509(309.50)$ & $3(5.00)$ & $129(221.00)$ & 1200 \\
& {$[81.14]$} & {$[12.90]$} & {$[128.60]$} & {$[0.80]$} & {$[38.30]$} & \\
Female & $521(352.00)$ & $249(312.50)$ & $110(309.50)$ & $7(5.00)$ & $313(221.00)$ & 1200 \\
& {$[81.14]$} & {$[12.90]$} & {$[128.60]$} & {$[0.80]$} & {$[38.30]$} &
\end{tabular}

Result: The chi-square statistic is 523.47. The p-value is $<0.00001$. The result is significant at $\mathrm{p}<$ .05 
Table 5a. Showing the Responses of Respondents towards the Concepts of Space Science Learnt from Textbooks

\begin{tabular}{lllll|l}
\hline S.No & Gender & Yes & No & No Idea & Total \\
\hline 1. & Male & 359 & 368 & 592 & 1319 \\
\hline 2. & Female & 238 & 466 & 377 & 1081 \\
\hline & & 597 & 834 & 969 & 2400 \\
\hline
\end{tabular}

*Mean $=800$, S.D $=188.31$

Note: From the above table, it is concluded that majority of the males $(n=592)$ do not have any idea about the concepts of space science learnt from textbooks. 368 respondents said no, while 359 said yes regarding the inclusion of concepts in the textbooks; whereas, majority of the female respondents $(n=466)$ did not learn any concepts from textbooks. 377 respondents do not have any idea, while 238 female respondents learnt the concepts from textbooks.

Table 5b. Showing the Application of Statistical Test (Chi-Square)

\begin{tabular}{|c|c|c|c|c|}
\hline & Yes & No & No Idea & Row Totals \\
\hline Male & $\begin{array}{l}359(328.10) \\
{[2.91]}\end{array}$ & $\begin{array}{l}368(458.35) \\
{[17.81]}\end{array}$ & $\begin{array}{l}592(532.55) \\
{[6.64]}\end{array}$ & 1319 \\
\hline Female & $\begin{array}{l}238(268.90) \\
{[3.55]}\end{array}$ & $\begin{array}{l}466(375.65) \\
{[21.73]}\end{array}$ & $\begin{array}{l}377(436.45) \\
{[8.10]}\end{array}$ & 1081 \\
\hline
\end{tabular}

Result: The chi-square statistic is 60.73 . The $p$-value is $<0.00001$. The result is significant at $p<.05$.

\section{Findings}

1. There is a limited content related to space science in the textbooks of Pakistan Studies and General Science.

2. The nature of the available content is theoretical

3. For field of interest, the value of chi-square statistic is 523.47, which shows that there is a significant difference among male and female respondents towards career selection (Mean= 480 and Standard Deviation=279.67).

4. For concepts of space science in textbooks through the lens of students, the value of chi-square is 60.73 , which shows that there is a significant difference among male and female responses (Mean= 800, S.D=188.31).

\section{Discussion}

Globally, various fields have emerged in science and technology, which dynamically opened up path to multidimensional aura and poured intellectual openness to build 
curiosity and contribute to sustainable development. Many scientific emerging fields such as astronomy, meteorology, synthetic biology are gradually seeping. Space Science emerged to propel quest of inquiry and brought developmental changes to the world; however, its sustenance lies in the disposition of interest amongst youth.

Space Science is a blooming field, which has lots of vista, based on exploration of veiled concepts. This field has prospects and opportunities (both professional and academic). Once, these fields were only confined to telecommunication; however, with leaps and bounds, the venues are expanding and opening doors of opportunities (Sacknoff \& David, 2015).

Career choice is a decision of individuals. Curriculum holds strong position in mediating healthy decision making to embark upon new fields. A research study was conducted in the United Kingdom to find perceptions and preferences of youth over career. Findings showed that gender stereotype, traditional jobs, and high perk influence occupation selection (Millward et al., 2006). Few studies highlighted the role of parents in facilitating career choices (Mutekwe et al., 2011; Otto, 2000). A research study, conducted in Pakistan highlighted societal inspiration, growth opportunities and perks as main factors for taking career decisions (Abbasi \& Sarwat, 2014). Another study endorsed profession of parents as a driving force for decision making (Saleem et al., 2014). Study of Aziz and Kamal (2012) supported traditional occupation as the first preference of most of the youth in Pakistan. A dissertation, written by one of the scholars (Malik, 2009) in Pakistan studied the influence of peer and parents in making career decisions by youth. The results revealed that both play important significant role. Other predicted variables which might influence career decision, but were not studied by the researcher include age, attachment, socioeconomic background and family structure.

In Pakistan, space science education is not promoted at school and college level. In this regard, the role of policy makers, institutions, teachers and civil society is crucial. Space science education has scope at higher education level in Pakistan. Unfortunately, youth are not much aware and interested to enter this field because teaching these concepts at grass-root level are alienated in Pakistan. Another reason is lack of the inclusion of concept in textbooks. If available, it is limited and conjectural.

Social studies is one of the most diversified and reflective subjects, which addresses global issues pertaining to various global challenges. It provides a sense of civic responsibility, at the same time combine diversification with various fields. From the present study, it is found that the textbook of Pakistan Studies (grade 9) is highly theoretical in nature. It is bombarded with history, ideology and other topics connected to Pakistan. There is a limited room for the concept of space, universe and planet in the book. Only two chapters share theoretical knowledge about these phenomena. It cannot, by any means, develop interest of students towards emerging fields (space science). From the previous textbooks, studied by the researcher to give strong base to this research study, it is revealed that these concepts do exist with balance proportion, but lack practicality. Further, as the level of study steps ahead, these concepts fade off from the textbooks. There is an unclear dimension for textbooks, as till grade 8, social studies is taught to the students in Pakistan, whereas at Matriculation level, these concepts are 
merged in Pakistan Studies. On the contrary, textbooks of Cambridge offer two subjects, i.e., History and Geography, as a part of Pakistan Studies and highlight many sturdy concepts. Overall, textbook of Social Studies/ Pakistan studies, published by Sindh Text Book Board fails to develop interest of students towards space science. Few public schools in Pakistan now also prefer teaching Cambridge books to the students till Grade 8 to avoid loopholes in disseminating up-to-date knowledge about space science, but no research study has so far been conducted to highlight its significance.

General Science has high potential in developing interest towards emerging fields, but has failed to justify its scope. From the research, it is concluded that all the chapters (Grade 9) are theoretical in nature. Chapter 11, in particular fails to grab interest of students, because it is unstructured and integrated with outdated knowledge. Although this chapter could have been a guiding source for students, it lacks integrated knowledge. Comparing it with the textbook of Physics Grade X, few technical concepts related to space science are included, yet hard to understand.

The role of gender in making career choice is observed from the survey. Majority of the females prefer medical and liberal arts, whereas majority of the male respondents favor commerce and engineering as their career field. Overall, majority of the respondents prefer choosing medical field followed by commerce, engineering, liberal arts and space science.

Pakistan Space and Upper Atmosphere Research Commission highlighted lack of awareness among youth as a contributing factor in derailing youth to adopt this profession (Dawn Newspaper, 2012).

Overall, majority either did not learn or have no idea about the inclusion of these concepts in textbooks. In the viewpoint of researcher, lack of availability of space science as a subject at school level could also be another reason for not choosing the field. Furthermore, guidance and counseling lacks professionalism due to which, teachers direct students to fall prey of traditional fields. Awareness program is a key to success, at the same time, role of teachers, their knowledge and positive attitude towards emerging field is also a crucial notion.

\section{Recommendations}

On the basis of research findings and experience of researcher, following productive recommendations are provided:

1. It is important to realize the importance of emerging fields such as space science. Unless we appreciate individuals to move towards new career paths, mindset of society will not change.

2. Curriculum of Science and Social Studies should be revised. It should be detached from political influence.

3. From Grade IX onwards, Pakistan studies should have two separate sections, i.e., History and Geography, in order to facilitate both aspects in detail. 
4. Content in the textbooks of Science and Social Studies should be revised with the inclusion of practical components related to space science. Inclusion of practical simulation content can mould and redirect the attention of future generations from traditional to transformative professions.

5. Teacher-training institutions should train teachers to play an effective role as counselors. They should have knowledge about emerging fields as well.

6. Specialized subject of space science should be introduced at secondary and higher secondary level. This subject should be piloted at national level through the support of civil society organizations.

7. Higher Education Commission should provide educational incentives to youth for joining emerging fields such as space sciences. More scholarship opportunities should be provided to students embarking upon the field of space science.

8. Guidance and Counseling unit should be established in all institutions to help students explore career opportunities in space science.

9. Awareness sessions at school and college level should be initiated. Media can also play an effective role to facilitate counseling.

\section{Conclusion}

Space Science and other emerging fields of science and technology will overshadow other fields in the near future. They hold unparalleled importance for the socioeconomic upliftment of Pakistan. For the global response and the need of time, it is a pressing need to consider this subject as crucial and promote it collectively. Counseling of youth and their career decisions in emerging fields should be given importance.

\section{References}

Abbasi, M.N., \& Sarwat, N. (2014). Factors inducing career choice: Comparative study of five leading professions in Pakistan. Pakistan Journal of Commerce and Social Sciences, 8 (3), 830-845.

Arulmani, G., Bakshi, A.J., Leong, F.T., \& Watts, T. (2014). Handbook of Career Development: International Perspectives. Springer Science \& Business Media.

Aziz, S., \& Kamal, A. (2012). Gender role attitudes and occupational aspirations of Pakistani adolescents. FWU Journal of Social Sciences, 6, 89-98.

Clutter, C. (2010). The effects of Parental Influence on Their Children's Career Choices (published dissertation). Kansas State University.

Dawn Newspaper. (2011, October 4). Pakistan needs trained manpower in space sciences. Retrieved from www.dawn.com/news/663956/pakistan-needs-trainedmanpower-in-space-sciences 
Dawn Newspaper. (2012, March 3). Final frontier: Space science education in Pakistan. Retrieved from www.dawn.com/news/699988/final-frontier-space-science-education-inpakistan

Foskett, N., \& Hemsley-Brown, J. (2002). Choosing Future. Routledge

Kaya, H., \& Boyuk, U. (2011). Attitudes towards physics lessons and physical experiements of the high school students. European Journal of Physics Education, 2(1).

Malik, S.N. (2009). Parental and Peer Influence on Career Decision Making Self Efficacy of Youth and Its Relationship with their Identity Development (published dissertation). National Institute of Psychology.

Millward, L., Houston, D., Brown, D., \& Barrett, M. (2006). Young people's job perceptions and preferences. Department of Psychology School of Human Sciences, University of Surrey Guildford .

Mohan, S. (2013). Student attitudes towards physics: concerns and solutions. Indian Journal of Science, 4(10).

Mutekwe, E., Modiba, M., \& Maphosa, C. (2011). Factors affecting female students' career choices and aspirations: A Zimbabwean example. Journal of Social Sciences, 29(2), 133-141.

Otto, L.B. (2000). Youth Perspectives on Parental Career Influence. Journal of Career Development, 27(2), 111-118.

Redish, E.F. (1994). The implications of cognitive studies for teaching physics. Am. J. Phys, 62, 796.

Rontos, K., \& Vavouras, I. (2013). Socioeconomic and Political Development: Their Measurement and Connections. Global Journal of Human Social Science and Political Science, 13(5), 50-65.

Russell, T. (2012). Student attitudes and aspirations towards science. In F. Barry., T. Kenneth., \& M. Campbell, Second international handbook of science education (597625). Springer International Handbooks of Education.

Sacknoff, S., \& David, L. (2015). Space Careers. International Space Business Council.

Saleem, N., Hanan, M.A., Saleem, I., \& Shamshad, R.M. (2014). Career selection: Role of parent's profession, mass media and personal choice. Bulletin of Education and Research, 36(2), 25-37.

Stefan, M., \& Ciomos, F. (2010). The 8th and 9th grades students' attitude towards teaching and learning process, Acta Didactica Napocensia, 3(3) 7-14.

The Express Tribune. (2014, November 13). Space programme: Youth participation needed. The Express Tribune. 